\title{
Arctic environmental change beyond instrumental records: introduction and overview
}

\author{
Colm Ó Cofaigh $^{1} \cdot$ Nina Kirchner $^{2} \cdot$ Grigory Fedorov $^{3} \cdot$ Riko Noormets $^{4} \cdot$ Anne de Vernal $^{5}$
}

Published online: 11 September 2018

c) Springer-Verlag GmbH Germany, part of Springer Nature 2018

\section{Introduction}

The Arctic is changing rapidly in response to recent climate warming. Understanding these changes and their causes, and predicting their future trajectory is a key challenge for science and one with significant socio-economic implications given the wider impact of rising sea levels due to polar ice sheet melt. While observations of recent change over the last few decades are of key importance, so too is an assessment of the longer term magnitude, rate and pattern of Arctic environmental change prior to the start of instrumental records.

The collection of papers in this special issue stems from a meeting of the PAST Gateways (Palaeo-Arctic Spatial and Temporal Gateways) network in Kristineberg, Sweden in 2017. Past Gateways is an IASC (International Arctic Science Council) endorsed thematic network, the goal of which is to understand Arctic environmental change across decadal to millennial scales and in the period preceding instrumental records. The network brings together Arctic scientists in the fields of glacial and marine geology, palaeoceanography, palaeoecology, permafrost and numerical modelling. The suite of papers in this special issue are organised into two broad themes, both of which are major foci of PAST

Colm Ó Cofaigh

colm.ocofaigh@durham.ac.uk

1 Department of Geography, Durham University, Durham DH1 3LE, UK

2 Department of Physical Geography, Bolin Centre for Climate Research, Stockholm University, SE-106 91 Stockholm, Sweden

3 Institute of Earth Sciences, St. Petersburg State University, St. Petersburg, Russia

4 Department of Arctic Geology, The University Centre in Svalbard (UNIS), PO Box 156, 9171 Longyearbyen, Norway

5 GEOTOP-UQAM, CP 8888, Montreal H3C 3P8, Canada
Gateways: (1) Arctic palaeoceanography and sea ice, and, (2) Growth and decay of Arctic glaciers and ice sheets.

\section{Overview of papers}

\section{Arctic palaeoceanography and sea ice}

The paper by Hörner et al. [1] uses biomarker studies of sediment cores to investigate sea ice distribution and polynya variability on the Kara Sea shelf over the last 12 ka. They find that sea ice cover in the central Kara Sea was most intense between 12.4 and 11.8 ka coinciding with the Younger Dryas, but reached a minimum between 10 and 8 ka during the Holocene Thermal Maximum. During the last $\sim 7 \mathrm{ka}$, increasing sea ice indicators suggest Holocene cooling, which the authors infer was probably due to decreasing summer insolation. In the southern Kara Sea fast ice expanded during the late Holocene and cyclical variability in sea ice cover is recorded.

The manuscript by Kremer et al. [2] presents the results of multi-biomarker analyses including HBIs (highly branched isoprenoids), sterols and alkenones from cores collected on the western Svalbard margin. One important finding is the demonstration of sea ice occurrence, even during the warmest phase of the last interglacial pointing to highly resilient Arctic sea ice in the climate system. Another important point raised in the manuscript concerns the regionalism in proxy records along the northern vs western margin of Svalbard, suggesting complex changes in ocean circulation east of Fram Strait, probably related to the Svalbard-Barents Sea Ice Sheet.

In a very different oceanographical context, the manuscript of Méheust et al. [3] focusses on the last glacial-deglacial transition and illustrates large amplitude variations in sea-surface temperature (SST), primary productivity and sea ice cover. The results suggest extensive sea-ice cover in the subarctic Pacific and Bering Sea during the last glacial 
maximum and reduced sea-ice cover coinciding with high summer SSTs during warm intervals of the Bølling/Allerød and early Holocene.

At the scale of the late Holocene, the high temporal resolution study of Kolling et al. [4] presents biomarker data documenting productivity changes in relation to sea ice cover. Short-term oscillations in biomarker fluxes are tentatively associated with modes of variability such as the Atlantic Multidecadal Oscillation. Comparison of the new biomarker data (HBI, IP25, sterols) with other proxy records from the same core (benthic foraminifera, dinocysts, diatoms, alkenones) point to productivity in complex environmental conditions likely marked by pronounced seasonality and oceanographic gradients.

Dipre et al. [5] reconstruct Plio-Pleistocene palaeoceanographic conditions in the western Arctic Ocean using a sediment core from the Northwind Ridge. They identify three major stratigraphic units corresponding to the upper-middle Quaternary, the lower Quaternary to Pliocene and lower Pliocene to possibly upper Miocene. Early Quaternary and older sediments show little impact from glaciation, reduced sea ice conditions and possibly enhanced Atlantic Water. A major deposition pulse at c. $5 \mathrm{Ma}$ is attributed to the onset of Pacific Water throughflow via the Bering Strait with an overlying hiatus spanning most of the Pliocene. The uppermost unit shows a strong glacial influence and perennial sea ice conditions.

Swärd et al. [6] use sedimentary proxies to study Pacific water inflow to the Arctic Ocean through the shallow Bering Strait after the LGM. They find that the first inflow of Pacific water occurred around $11 \mathrm{cal} \mathrm{ka} \mathrm{BP.} \mathrm{After} \mathrm{the} \mathrm{initial,}$ topographically-controlled, flow into the Herald Canyon, different clay mineral ratios suggest low sedimentation rates mainly from local Chukchi Sea sources until c. $8.5 \mathrm{cal} \mathrm{ka}$ BP. Subsequent Holocene sedimentation was dominated by the interplay of Pacific water and the enhanced advection of shelf water from the East Siberian Sea, consistent with modern oceanographic conditions in the region.

Schreck et al. [7] investigate the upper Pleistocene sediment stratigraphy of the East Siberian and Chukchi margins of the Arctic Ocean. Using geophysical properties and XRF data on elemental composition of several sediment cores, they establish a regional stratigraphy and correlation with the adjacent Mendeleev and Northwind Ridges. Their proposed stratigraphic framework indicates decreasing sedimentation rates from the East Siberian margin east- and northwards, which they attribute to increased distance from the main sediment sources. This leads the authors to suggest that the most recent major ice sheet advanced from the East Siberian margin to the Arctic Ocean during MIS 4/3.

Seidenstein et al. [8] use calcareous microfossil assemblages in high resolution sediment cores to investigate Late Holocene palaeoceanography on the western Arctic continental shelf. Radiocarbon dated benthic foraminiferal and ostracode records from sites in the Herald Canyon (Chukchi Sea shelf) and Beaufort Sea shelf are compared. Microfaunal changes from the Beaufort site point to an increase in the influence of Pacific Water and a decrease in sea ice cover. A similar picture emerges from the Herald Canyon data for the last few centuries, although assemblage differences between the two sites may reflect a comparatively greater influence of Pacific Water on the Chukchi shelf, compared to the more distal Beaufort shelf.

\section{Growth and decay of Arctic glaciers and ice sheets}

Larsen et al. [9] present new sedimentological, geomorphological and chronological data from the Van Mijenfjorden region, Svalbard which suggests the occurrence of numerous glacial advances in the period from the Late Weichselian to the Little Ice Age (LIA). Glacial deposits in the area record differing sizes and styles of ice flow during Lateglacial and Holocene deglaciation as well as regrowth and readvance during the early Holocene, Neoglacial and LIA. Glacier behaviour was driven by climate and internal dynamic controls, although glacier dynamics outpaced climate on several occasions during the Holocene.

Sedimentological and stratigraphical investigations of Late Quaternary deposits at Kongsfjordhallet, northwest Svalbard, by Alexanderson et al. [10] provide evidence for at least three and possibly as many as five, glacioisostatically-induced, high relative sea level events which imply preceding regional glaciations. Integration with records from elsewhere on northwestern Svalbard indicate there were six major glacial advances during the last $200 \mathrm{ka}$. Two of these occurred during the Saalian and four during the Weichselian implying a highly dynamic Barents Sea Ice Sheet.

Fransner et al. [11] reconstruct Late Weichselian ice stream configuration and dynamics on the northern Svalbard margin using marine geophysics and sediment coring. Seismic data indicates that streaming ice reached the continental shelf edge through Albertini Trough on multiple occasions during the Quaternary. During the LGM grounded ice reached the mouth of the trough. Radiocarbon dated sediment cores indicate that the central part of the shelf just west of Albertini Trough was ice free by $14.0 \mathrm{ka} \mathrm{BP}$ with the rate of retreat increasing as the ice sheet pulled back across the shelf.

Farnsworth et al. [12] use geomorphic mapping combined with ${ }^{14} \mathrm{C}$ and ${ }^{10} \mathrm{Be}$ cosmogenic surface exposure dating to reconstruct Greenland Ice Sheet extent during the Holocene in Nunatarssuaq, Northwest Greenland. Older ${ }^{10} \mathrm{Be}$ ages suggest nuclide inheritance and a minimally erosive ice sheet at the LGM. Subfossil plants date to $\sim 4.7 \mathrm{cal} \mathrm{ka} \mathrm{BP}$ and record a period when the ice sheet was smaller than present, but this was followed subsequently by a significant advance of outlet 
glaciers at $~ 3.2-2.1 \mathrm{ka}$. Late Holocene ice-marginal fluctuations are less well constrained, but, in conjunction with the 3.2-2.1 advance, are consistent with Holocene insolation driven cooling.

Briner and Hormes [13] report on the ${ }^{10} \mathrm{Be}$ dating of glacial erratics, moraine boulders and a bedrock surface from Bjørnøya, Svalbard. They use these data to reconstruct the final stages of the last deglaciation of the Barents Sea Ice Sheet from Bjørnøya and the surrounding Spitsbergenbanken, southern Barents Sea. Final break-up overlapped with the early Younger Dryas and implies that Younger Dryas cooling did not actually reverse overall glacier recession in this region.

The last deglaciation of the Kola Peninsula, northwest Russia, is described by Lunkka et al. [14] in the wider context of reconstructing the evolution of the Late Pleistocene paleoenvironments of the area. The first ice advance occurred in the Early Weichselian and was followed by the establishment of glaciolacustrine conditions. Evidence for only one further advance is recorded which the authors infer was most likely related to advance of the LGM Scandinavian Ice Sheet. The prominent Keriva II and Keiva I end moraines are Younger Dryas interlobate features.

Acknowledgements We acknowledge all the authors for their contributions to this special issue. Thanks also to all the reviewers for their efforts and valuable feedback. We are also grateful to the Editor in Chief Dr. Henning Bauch for his encouragement and help during the planning and preparation of this special issue.

\section{References}

1. Hörner T, Stein R, Fahl K (2018) Paleo-sea ice distribution and polynya variability on the Kara Sea shelf during the last $12 \mathrm{ka}$. arktos 4(1):6

2. Kremer A, Stein R, Fahl K, Bauch H, Mackensen A, Niessen F (2018) $190 \mathrm{ka}$ Biomarker record revealing interactions between sea ice, Atlantic Water inflow and ice sheet activity in eastern Fram Strait. arktos 4(1):22
3. Méheust M, Stein R, Fahl K, Gersonde R (2018) Sea ice variability in the subarctic North Pacific and adjacent Bering Sea during the past $25 \mathrm{ka}$ : new insights from $\mathrm{IP}_{25}$ and $\mathrm{U}^{\mathrm{k}}{ }_{37}$ proxy records. arktos 4(1): 8

4. Kolling HM, Stein R, Fahl K, Perner K, Moros M (2018) New insights into sea ice changes over the past $2.2 \mathrm{kyr}$ in Disko Bugt, West Greenland. arktos 4(1):11

5. Dipre GR, Polyak L, Kuznetsov AB, Oti EA, Ortiz JD, Brachfeld SA, Xuan C, Lazar KB, Cook AE (2018) Plio-Pleistocene sedimentary record from the Northwind Ridge: new insights into palaeoclimatic evolution of the western Arctic Ocean for the last $5 \mathrm{Ma}$. arktos 4(1):24

6. Swärd H, O'Regan M, Pearce C, Semiletov I, Stranne C, Tarras H, Jakosson M (2018) Sedimentary proxies for Pacific water inflow through the Herald Canyon, western Arctic Ocean. arktos 4(1):19

7. Schreck M, Nam S-I, Polyak L, Vogt C, Kong G-S, Stein R, Matthiessen J, Niessen F (2018) Improved Pleistocene sediment stratigraphy and palaeoenvironmental implications for the western Arctic Ocean off the East Siberian and Chukchi margins. arktos 4(1):21

8. Seidenstein JL, Cronin TM, Gemery L, Keigwin LD, Pearce C, Jakobsson M, Coxall HK, Wei EA, Driscoll NW (2018) Late Holocene paleoceanography in the Chukchi and Beaufort Seas, Arctic Ocean, based on benthic foraminifera and ostracodes. arktos 4(1):23

9. Larsen E, Lyså A, Rubensdotter L, Farnsworth WR, Jensen M, Nadeau MJ, Ottesen D (2018) Lateglacial and Holocene glacier activity in the Van Mijenfjorden area, western Svalbard. arktos $4(1): 9$

10. Alexanderson H, Henriksen M, Ryen HT, Landvik JY, Peterson G (2018) $200 \mathrm{ka}$ of glacial events in NW Svalbard: an emergence cycle facies model and regional correlations. arktos 4(1):3

11. Fransner O, Noormets R, Chauhan T, O'Regan M, Jakobsson M (2018) Late Weichselian ice stream configuration and dynamics in Albertini Trough, Northern Svalbard margin. arktos 4(1):1

12. Farnsworth LB, Kelly MA, Bromley GRM, Axford Y, Osterberg EC, Howley JA, Jackson MS, Zimmerman SR (2018) Holocene history of the Greenland Ice-Sheet margin in Northern Nunatarssuaq, Northwest Greenland. arktos 4(1): 10

13. Briner JP, Hormes A (2018) ${ }^{10}$ Be dating the last deglaciation of Bjørnøya, Svalbard. arktos 4(1):17

14. Lunkka JP, Kaparulina E, Putkinen N, Saarnisto M (2018) Late Pleistocene palaeoenvironments and the last deglaciation on the Kola Peninsula, Russia. arktos 4(1):18 